\title{
Pembuatan Sistem Administrasi Tugas Akhir Berbasis Teknologi Informasi Pada Program Studi S1 Teknik Kimia UPN "Veteran" Yogyakarta
}

\author{
Aditya Kurniawan ${ }^{(1)}$, Yusmardhany Yusuf(2), Yulius Deddy Hermawan ${ }^{(3)}$, Purwo Subagyo ${ }^{(4)}$ \\ Program Studi S1 Teknik Kimia UPN "Veteran” Yogyakarta \\ Kampus I UPN “Veteran” Yogyakarta, Jln. Lingkar Utara 104, Condongcatur, Sleman, DIY \\ e-mail : aditya.kurniawan@upnyk.ac.id ${ }^{(1)}$
}

\begin{abstract}
The final assignment administration in the chemical engineering undergraduate study program, UPN "Veteran" Yogyakarta is still applied manually. This has caused several problems include impracticality and data-keeping problems. An IT-based administration system is built to overcome these problems. The system involves all the stakeholders of the final assignment; include students, supervisor, advisor, final assignment coordinator, and department management to maximize its benefit. The system is developed as a web-based application using PHP language in the Laravel framework and using MySQL as the database server. The developed system is capable to facilitate either the students in handling the administration procedure or the department in monitoring, controlling, and managing the final assignment data.
\end{abstract}

\section{Keywords: final assignment administration system, PHP, Laravel, MySQL}

Pelayanan administrasi tugas akhir di prodi S1 teknik kimia UPN "Veteran" Yogyakarta selama ini masih secara manual. Hal ini menimbulkan beberapa masalah seperti ketidakpraktisan dan kendala dalam pengarsipan data. Untuk mengatasi permasalahan tersebut, dibuatlah suatu sistem administrasi tugas berbasis teknologi informasi. Sistem administrasi ini melibatkan semua pengguna yang berkepentingan seperti: mahasiswa, dosen pembimbing, dosen wali, koordinator tugas akhir, hingga pengurus jurusan. Hal ini agar manfaat sistem administrasi ini dapat dimanfaatkan secara luas. Sistem administrasi dibuat dalam bentuk aplikasi berbasis web menggunakan bahasa pemrograman PHP yang dibangun dengan framework Laravel dan database MySQL. Sistem administrasi yang dibangun dapat mempermudah mahasiswa dalam mengurus administrasi tugas akhir maupun jurusan dalam pemantauan, pengendalian dan pengelolaan data tugas akhir mahasiswa.

Kata Kunci : sistem administrasi tugas akhir, PHP, Laravel, MySQL

\section{PENDAhULUAN}

Program studi S1 Teknik Kimia UPN "Veteran" Yogyakarta memiliki visi untuk mencetak lulusan teknik kimia yang berjiwa bela negara di era global. Visi ini kemudian dijabarkan dalam misi dan direalisasikan dalam suatu struktur kurikulum pembelajaran. Kurikulum pembelajaran ini terdiri atas kurikulum dasar dan kurikulum inti Teknik Kimia yang terdistribusi ke dalam 8 semester. Kegiatan pembelajaran diakhiri dengan tugas akhir yang bertujuan mengevaluasi secara keseluruhan penguasaan mahasiswa terhadap kompetensi lulusan teknik kimia, yang meliputi kerja praktek industri, penelitian, dan skripsi prarancangan pabrik kimia. Dalam struktur kurikulum, penelitian dilakukan pada semester 6 , kerja praktik industri di semester 7 , dan skripsi di semester 8. Seluruh rangkaian tugas akhir ini bersifat wajib yang menentukan kelulusan mahasiswa sebagai sarjana. Oleh karena itu, guna mendukung kelancaran pelaksanaan tugas akhir, ditunjuklah koordinator untuk masing-masing tugas akhir tersebut. Tugas dari koordinator adalah melakukan pencatatan dan verifikasi mahasiswa yang mengambil tugas akhir, mendistribusikan pembimbing, serta menyiapkan dokumen untuk mendukung administrasi kegiatan tugas akhir. Koordinasi ini penting agar kegiatan tugas akhir tersebut dapat berjalan dengan lancar, terpantau kemajuannya, dan dapat dilakukan mitigasi jika terjadi hambatan yang dialami oleh mahasiswa.

Namun, dengan jumlah mahasiswa per angkatan yang banyak, kegiatan administrasi yang selama ini dilakukan tidak praktis dan kurang fleksibel. Hal ini karena beberapa kegiatan administrasi masih dilakukan secara manual, seperti pencatatan mahasiswa yang mendaftar 
atau mahasiswa yang melakukan pengumpulan laporan. Data yang masih bersifat manual/analog membuat pengolahan, analisis dan evaluasi data menjadi sulit untuk dilakukan. Kesulitan ini lebih dirasakan pada saat monitoring/evaluasi pembelajaran maupun akreditasi yang memerlukan data-data seperti lama pengerjaan tugas akhir, jumlah mahasiswa yang mengambil tugas akhir, dll untuk pengisian borang. Di sisi lain, pengurus jurusan juga mengalami kesulitan untuk melakukan pengambilan keputusan terkait kegiatan tugas akhir, karena proses analisis data yang kurang fleksibel. Selain itu, data yang masih manual menyebabkan data rawan mengalami kerusakan/hilang. Di samping itu, prosedur yang bersifat manual juga menyebabkan proses administrasi menjadi kurang praktis.

Teknologi informasi telah menguasai banyak sendi kehidupan manusia, mulai dari dunia bisnis, perbankan, ekonomi, sosial budaya, dan tentu saja di dunia pendidikan terutama pendidikan tinggi. Dengan jumlah mahasiswa yang banyak, pengelolaan administrasi secara manual di perguruan tinggi tentu tidak praktis dan memerlukan sumberdaya manusia serta waktu yang banyak. Untuk itu, penggunaan teknologi informasi untuk pengelolaan pendidikan, sudah menjadi bagian yang tidak terpisahkan. Hampir seluruh aspek pengelolaan pendidikan sudah disentuh oleh teknologi informasi, dengan berbagai variannya. Mulai dari proses penerimaan mahasiswa baru (Jannah, Bayturrohman, \& Kurniawan, 2017), pembayaran uang kuliah (Hidayati \& Hadi, 2017), perwalian, e-learning (Susilo \& Rohman, 2019), akreditasi (Sukamto, Nugroho, \& Winarno, 2016), pengelolaan tugas akhir, hingga mahasiswa tersebut lulus dan menjadi alumni (Raafi'Udin, 2017).

Khusus mengenai pengelolaan tugas akhir, tinjauan yang digunakan meliputi perancangan hingga penerapan. Aplikasi yang dikembangkan berupa aplikasi berbasis web yang mengelola pengajuan proposal, pengajuan ujian, persetujuan pembimbing, penilaian dan pemantauan kemajuan pengerjaan tugas akhir, dan pencarian data mahasiswa. Adapun pihak yang berkepentingan pada sistem ini adalah mahasiswa, dosen pembimbing, dosen penguji, pembimbing akademik, serta pengurus jurusan (Nugroho \& Putra, 2016). Adapun alur kerja pengembangan sistem ini secara umum terdiri atas: studi pendahuluan, pengumpulan dan pengolahan data, perancangan sistem (interface, database, dan aplikasi), dan analisis (Rendro Prasetyo, 2010). Manfaat yang diperoleh dengan penggunaan teknologi informasi ini antara lain: pertemuan tatap muka tidak diharuskan sehingga dapat meningkatkan fleksibilitas proses pengelolaan akademis, kemudahan dalam mengakses informasi, mempermudah dan mempercepat kegiatan administrasi, serta kemudahan-kemudahan lainnya (Musmini \& Kertiasih, 2016).

Sistem administrasi tugas akhir yang akan dikembangkan pada penelitian ini merupakan aplikasi berbasis website (web based application) yaitu aplikasi yang bisa diakses menggunakan browser web (Taftayani, Gumilang, \& Lubis, 2019). Aplikasi berbasis web dikembangkan menggunakan bahasa pemrograman yang didukung oleh web browser seperti HTML, JavaScript, atau CSS, sehingga bisa diakses langsung oleh pengguna melalui browser internet. Hal ini berbeda dengan aplikasi berbasis desktop yang memerlukan proses instalasi terlebih dahulu sebelum digunakan, dan tidak bisa digunakan secara remote.

Aplikasi berbasis website berbasis pada arsitektur dinamis dari suatu halaman web berupa interaksi dua arah antara dua pihak, yaitu client dan server. Client berperan memberikan request (permintaan) kepada server untuk menampilkan sumber daya/data yang diperlukan dengan suatu protocol tertentu. Kemudian server menanggapi permintaan tersebut dan memberikan respon untuk memenuhi permintaan client. Jika dalam memenuhi permintaan client diperlukan suatu operasi pemrograman atau data yang tersimpan dalam database, maka diperlukan aplikasi tambahan, yaitu database server.

Dalam penerapannya, client adalah perangkat yang terpasang di dalamnya browser web (Firefox, Internet Explorer, Safari, dII), sedangkan server adalah perangkat komputer dengan spesifikasi tertentu, yang terinstal di dalamnya web server untuk melayani permintaan client. Masing-masing pihak memerlukan bahasa pemrograman (script) khusus, sesuai dengan fungsinya. Untuk client, bahasa pemrograman yang digunakan antara lain HTML, Javascript, dan CSS. Sedangkan untuk server, bahasa pemrograman yang biasa digunakan antara lain PHP, ASP, JSP, dll. 
Secara umum, aplikasi berbasis web memiliki beberapa kelebihan, antara lain (Solichin, 2016):

- Tidak memerlukan instalasi pada sisi pengguna (user)

- Dapat diakses secara remote tanpa halangan jarak, selama komputer pengguna terhubung ke komputer server

- Data input/output hasil aplikasi tersimpan pada server sehingga tidak memberatkan pengguna dalam hal penyimpanan data

- Dapat digunakan lintas platform sistem operasi (Windows, Linux, MacOS)

Pengembangan suatu aplikasi web memerlukan suatu pendekatan yang menyeluruh, yang mencakup aspek teknis serta filosofis, berdasarkan tujuan yang dicapai dari pengembangan aplikasi tersebut. Penggunaan model konseptual untuk menggambarkan hubungan fungsional antar bagian dari aplikasi web banyak diaplikasikan, antara lain dengan penggunaan use case diagram atau skenario (Al-Fedaghi, 2011). Skema pengembangan dengan model ini disebut dengan RUP (Rational Unified Process), yang merupakan metode yang mengumpulkan berbagai best practices dalam rekayasa perangkat lunak. Beberapa tahap yang harus ditempuh dalam pengembangan aplikasi dengan metode ini adalah (Setiawan \& Nurfadilah, 2016):

- Inception: dalam tahap ini, konsep dasar dari aplikasi ditentukan, seperti siapa penggunanya (actor), tujuan, serta manfaat yang hendak diperoleh oleh pengguna.

- Elaboration, berupa pembuatan diagram yang diperlukan dalam visualisasi konsep aplikasi yang akan dikembangkan.

- Construction, berupa perancangan antarmuka, struktur menu, dan implementasi program dalam bentuk bahasa pemrograman (coding)

- Transition, berupa pengujian aplikasi, pelatihan, dan peluncuran ke pengguna.

Di internal UPN "Veteran" Yogyakarta, penggunaan teknologi informasi telah diterapkan untuk keperluan administrasi akademik melalui aplikasi CBIS. Hal ini tentu saja selaras dengan misi UPN, yaitu Pengembangan sistem manajemen universitas berdasarkan prinsip-prinsip good university governance dan nilai-nilai institusi dalam rangka menciptakan dan meningkatkan kualitas pelaksanaan Tridharma perguruan tinggi. Pemanfaatan teknologi informasi secara umum dapat meningkatkan produktivitas kerja dan kemudahan akses informasi, dan untuk masa sekarang ini mutlak dibutuhkan.

Oleh karena itu, penelitian ini dilakukan untuk menerapkan teknologi informasi dalam sistem administrasi tugas akhir mahasiswa prodi S1 Teknik Kimia. Administrasi tugas akhir, dari yang semula bersifat manual akan diubah menjadi berbasis teknologi informasi. Mahasiswa yang sebelumnya harus datang langsung ke tata usaha dan mengisi form pendaftaran, nantinya cukup melakukan pendaftaran dari laptop masing-masing. Kemudian pencatatan tanggaltanggal penting, seperti tanggal pendaftaran, tanggal pengumpulan berkas maupun laporan, akan tercatat secara otomatis ke dalam sistem database, serta kemudahan-kemudahan lainnya.

\section{METODOLOGI}

Sebagaimana pengembangan sistem berbasis teknologi informasi lainnya, maka pengembangan sistem administrasi tugas akhir ini akan terbagi ke dalam 3 tahap, yaitu studi pendahuluan, pengembangan perangkat lunak (aplikasi/software) dan instalasi perangkat keras (hardware). Perangkat lunak yang dimaksud adalah aplikasi (web-based) dan database. Adapun perangkat keras yang akan dipasang meliputi server dan jaringan internet. Secara umum, metodologi penelitian yang akan dilakukan ditunjukkan oleh Gambar 1. 


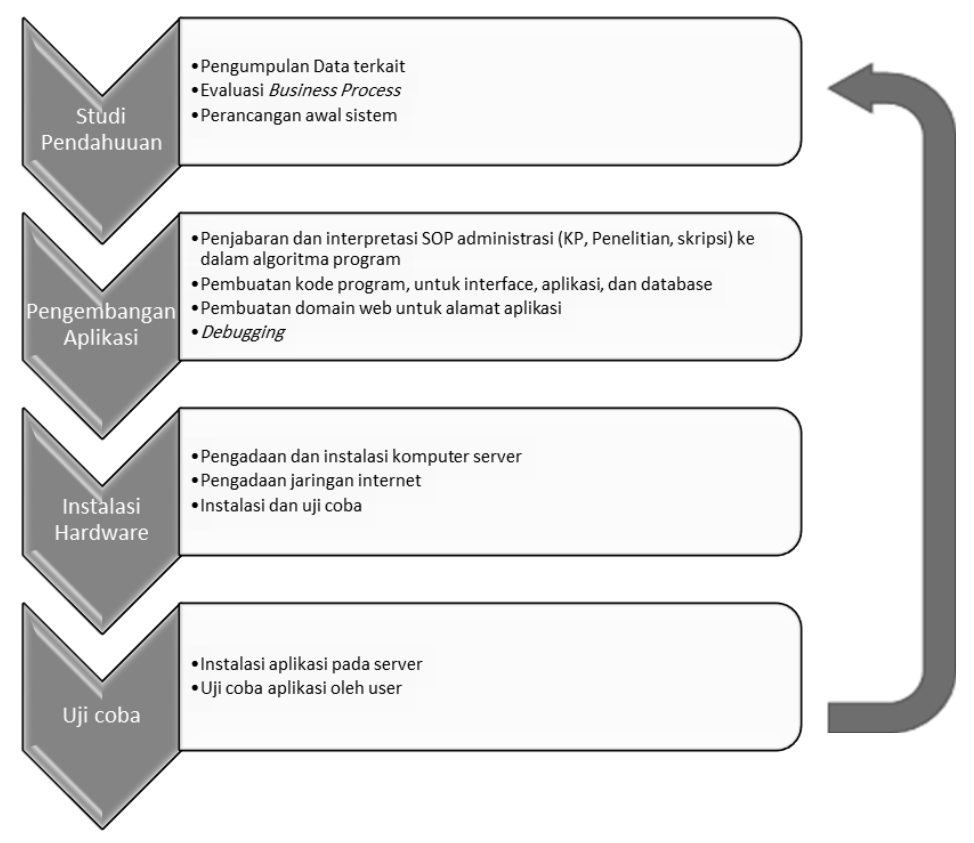

\section{Gambar 1 Metodologi Pengembangan Sistem Administrasi Tugas Akhir}

Dalam pembuatan sistem administrasi tugas akhir ini, platform website digunakan karena dengan menggunakan website, aplikasi ini akan mudah diakses oleh para pengguna di manapun dan kapanpun. Selain itu, dengan basis website, maka aplikasi dapat diakses dari berbagai macam perangkat dengan sistem operasi yang berbeda-beda, baik itu perangkat berbasis sistem operasi Windows, Linux, MacOS, maupun perangkat mobile Android. Hal ini dapat meningkatkan aksesibilitas dan fleksibilitas penggunaan aplikasi.

Adapun dalam pengembangan aplikasi website, bahasa pemrograman yang digunakan adalah PHP dengan Laravel sebagai framework (kerangka kerjanya). Laravel merupakan sebuah framework yang memiliki beberapa fitur untuk mendukung pengembangan suatu aplikasi web, antara lain modular packaging system serta perangkat yang dapat mempermudah proses penerapan dan pemeliharaan suatu aplikasi. Sebuah framework digunakan dalam pengembangan aplikasi website karena beberapa alasan:

- Menghindari pengulang-ulangan (repetitive work) dalam proses coding. Laravel menyediakan library-library yang secara tipikal telah digunakan dalam suatu aplikasi web. Dengan adanya library ini, maka dalam penyusunan suatu proses /fungsi dalam aplikasi, maka tidak perlu melakukan coding dari awal. Sebagai contoh adalah library untuk fitur export data ke dalam file Ms Excel, dalam Laravel telah tersedia library PHPExcel sehingga yang perlu dilakukan adalah tinggal memasang library ini dalam coding program.

- Keamanan/security. Laravel merupakan suatu project open source yang berbasis komunitas. Oleh karena itu, hampir setiap fitur atau library yang ada di dalamnya telah diuji oleh banyak programmer di seluruh dunia. Oleh karena itu, jika ditemukan potensi celah keamanan dalam salah satu kode programnya, akan lebih cepat dilakukan dan segera dikeluarkan update untuk menutup celah tersebut.

- Kualitas. Dengan pengembangan berbasis komunitas, maka tiap syntax sugar (syntax baru yang dibuat untuk menyederhanakan syntax bawaan PHP) telah diuji oleh banyak developer, sehingga kualitasnya lebih terjamin.

- Memudahkan kerja tim. Hal ini karena Laravel memiliki dokumentasi yang cukup lengkap sebagai acuan bagi tim programmer untuk mengembangkan aplikasinya.

- Lebih menghemat waktu dalam proses pengembangan aplikasi berbasis website. Artinya untuk fungsi-fungsi dasar yang secara tipikal ada dalam suatu sistem informasi sudah tersedia template-nya, sehingga tidak diperlukan proses coding ataupun pembangunan aplikasi dari nol. Hal ini tentu akan lebih menghemat waktu pengembangan. 
Adapun secara umum, dalam pengembangan aplikasi sistem informasi tugas akhir ini, digunakan seperangkat peralatan (tools) pemrograman yang ditunjukkan dalam Tabel 1. Semua tools yang digunakan untuk mengembangkan aplikasi merupakan tools yang paling terbaru. Hal ini guna menjamin kompatibilitas aplikasi yang dihasilkan terhadap berbaik browser yang tersedia saat ini.

Tabel 1 Perangkat Pemrograman yang Digunakan

\begin{tabular}{|lc|}
\hline \multicolumn{2}{|c|}{ Development Tools } \\
\hline Text editor & Visual Studio Code \\
Sistem operasi & Linux \\
Bahasa Pemrograman & PHP v.7.4 \\
Framework & Laravel \\
Desain template & Admin Mart \\
Platform & Website \\
Database & MySQL 8.0 \\
\hline
\end{tabular}

\section{HASIL DAN PEMBAHASAN}

\subsection{Rancangan Konseptual Aplikasi}

Dalam pengembangannya, aplikasi ini menggunakan konsep semi-daring (semi-online), yaitu proses pengurusan administrasi tugas akhir mengkombinasikan sistem daring dan sistem konvensional (manual). Hal ini karena pada kondisi sekarang, SOP administrasi secara manual telah dijalankan. Sehingga, jika langsung dilakukan migrasi secara drastis menjadi sistem daring, dikhawatirkan proses pengurusan administrasi akan terhambat. Oleh karena itu, proses migrasi perlu dijalankan secara bertahap. Sebagai contoh adalah pada saat mahasiswa mengajukan pendaftaran mata kuliah penelitian, maka sistem administrasi menyediakan menu pesan notifikasi kepada dosen wali serta tombol persetujuan. Namun, untuk mendapatkan persetujuan dari dosen wali, mahasiswa tetap perlu meminta tanda tangan dosen wali pada form yang telah ditentukan. Diharapkan hal ini hanya berlangsung pada masa migrasi. Adapun setelah proses administrasi secara daring dapat dijalankan dengan lancar, maka proses secara daring-penuh bisa diterapkan.

Dalam perancangan sistem administrasi, alur proses administrasi yang dijalankan mengikuti SOP administrasi tugas akhir (penelitian, kerja praktik, dan skripsi) yang terlampir pada bagian akhir dari laporan ini. Aktor yang terlibat dalam prosedur sistem administrasi ini adalah:
a. Mahasiswa
b. Dosen
c. Admin sistem
d. Admin tata usaha

Secara umum, mahasiswa memiliki fungsi utama untuk menjalankan SOP (fungsi inisiasi). Sedangkan dosen menjalankan beberapa peran, yaitu sebagai dosen wali, dosen pembimbing, koordinator tugas akhir, serta peran pengurus jurusan (koordinator program studi dan ketua jurusan). Seorang dosen mungkin untuk memiliki lebih dari satu peran. Peran sebagai dosen wali dan dosen pembimbing merupakan peran dasar dosen. Adapun peran lain merupakan peran tambahan. Sebagai aktor pendukung sistem adalah administrasi TU dan administrasi sistem. Fungsi masing-masing aktor tersebut ditunjukkan pada Tabel 2

Tabel 2 Tabulasi Aktor Yang Berperan Dalam Aplikasi Serta Fungsinya

\begin{tabular}{cccc}
\hline No & Aktor & \multicolumn{1}{c}{ Peran } & Fungsi \\
\hline 1. & Mahasiswa & Mahasiswa & • Registrasi, Pengajuan, pendaftaran, upload \\
\hline 2. & Dosen & Dosen Wali & • Persetujuan pengajuan mata kuliah tugas akhir \\
\hline
\end{tabular}




\begin{tabular}{|c|c|c|c|}
\hline No & Aktor & Peran & Fungsi \\
\hline & & $\begin{array}{l}\text { Dosen } \\
\text { Pembimbing }\end{array}$ & $\begin{array}{l}\text { - Persetujuan judul } \\
\text { - Persetujuan bimbingan } \\
\text { - Persetujuan pengajuan form kerja praktik } \\
\text { - Persetujuan proposal } \\
\text { - Persetujuan laporan } \\
\end{array}$ \\
\hline & & $\begin{array}{l}\text { Koordinator Tugas } \\
\text { Akhir }\end{array}$ & $\begin{array}{l}\text { - Distribusi pembimbing } \\
\text { - Persetujuan judul }\end{array}$ \\
\hline & & $\begin{array}{l}\text { Pengurus Jurusan } \\
\text { (Ketua Jurusan \& } \\
\text { Koordinator Prodi) }\end{array}$ & $\begin{array}{l}\text { - Observasi mahasiswa \& pembimbing } \\
\text { - Pengendalian }\end{array}$ \\
\hline 3. & Admin TU & Admin TU & $\begin{array}{l}\text { - Upload nilai } \\
\text { - Rekap pengajuan seminar/pendadaran }\end{array}$ \\
\hline 4. & $\begin{array}{l}\text { Admin } \\
\text { Sistem }\end{array}$ & Admin Sistem & - Pengelolaan database \\
\hline
\end{tabular}

Masing-masing aktor berkepentingan terhadap tiap tahapan pelaksanaan tugas akhir, sesuai dengan fungsi masing-masing. Deskripsi mengenai fungsi masing-masing aktor dapat digambarkan sebagai use case diagram, sebagaimana ditunjukkan oleh Gambar 2.

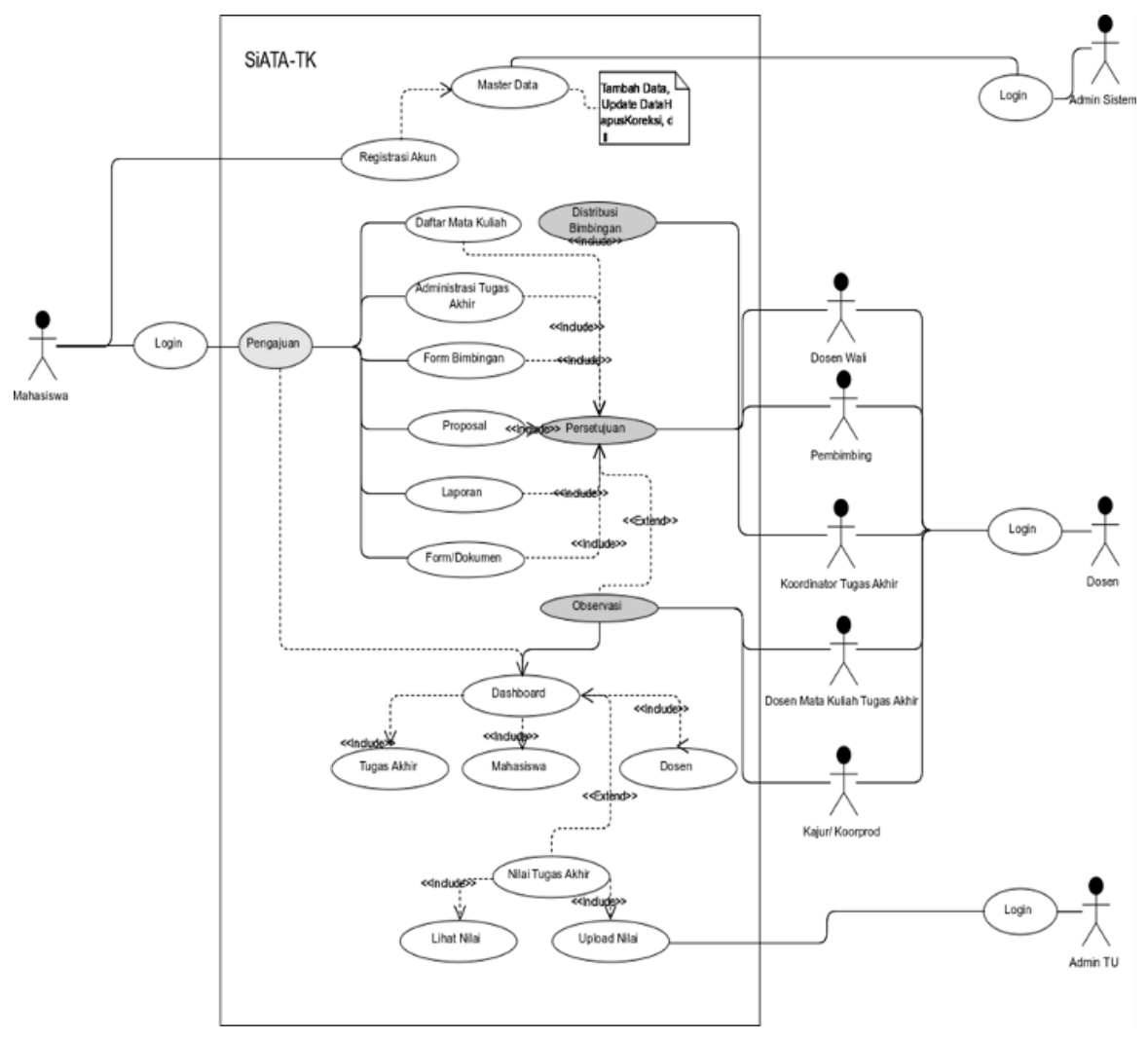

Gambar 2 Use Case Diagram Sistem Administrasi Tugas Akhir Teknik Kimia

Setelah diketahui hubungan fungsional dari tiap aktor serta fungsi yang dijalankan, maka langkah selanjutnya adalah membuat sketsa tampilan aplikasi atau disebut dengan mockup. Sketsa dilakukan untuk tampilan masing-masing peran, yaitu sebagai mahasiswa, dosen, koordinator tugas akhir, pengurus jurusan, serta admin. Contoh salah satu halaman sketsa aplikasi ditampilkan pada Gambar 3. 

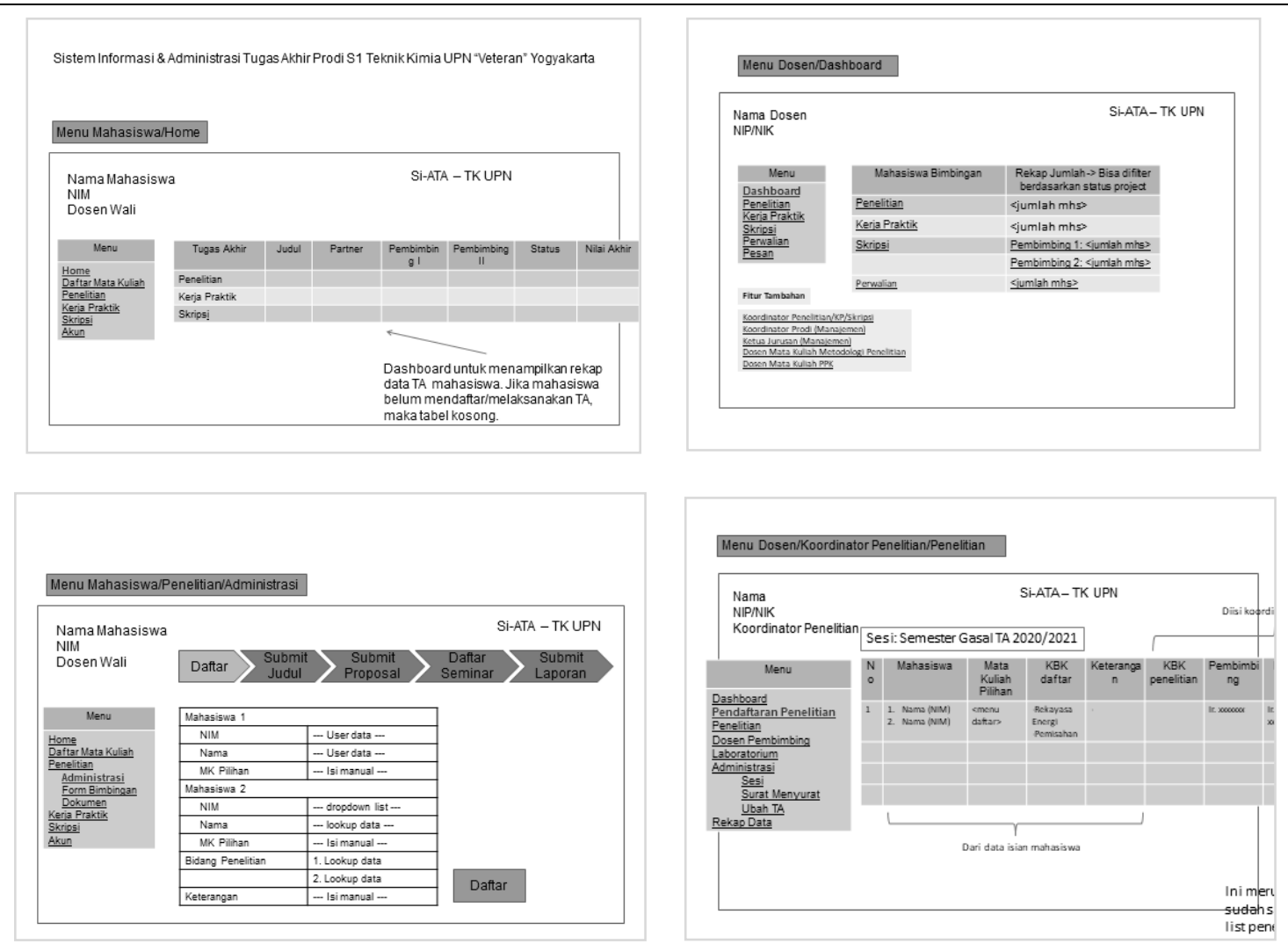

Gambar 3 Tampilan Sketsa / Mockup Aplikasi

\subsection{Hasil Pembuatan Aplikasi}

Dengan menggunakan tools pemrograman yang telah dijelaskan sebelumnya, maka serangkaian program disusun sesuai dengan bahasa pemrograman yang digunakan. Serangkaian program yang kemudian nantinya akan di-compile oleh compiler dan akhirnya bisa dijalankan oleh sistem operasi, disebut dengan source code. Source code yang dieksekusi oleh sistem operasi akan ditampilkan dalam bentuk antarmuka yang dapat digunakan oleh pengguna (user).

Pada bagian ini ditunjukkan tampilan antarmuka aplikasi sistem administrasi tugas akhir yang telah dibuat. Pada Gambar 4 ditampilkan halaman login, pada saat user mengakses alamat website sistem aplikasi. Untuk bisa masuk ke aplikasi, maka pengguna harus memasukkan username serta password. Khusus untuk mahasiswa, maka mereka harus membuat username sendiri dengan cara klik tombol Registrasi Mahasiswa. Setelah itu, mahasiswa akan diarahkan untuk mengisi data-data terkait seperti NIM, nomor ponsel, serta alamat email. Selanjutnya, aplikasi akan mengirimkan link aktivasi akun ke alamat email yang telah diisikan oleh mahasiswa pada saat registrasi. Adapun pengguna selain mahasiswa (dosen dan tenaga administrasi) akan dibuatkan username dan password oleh admin sistem. 


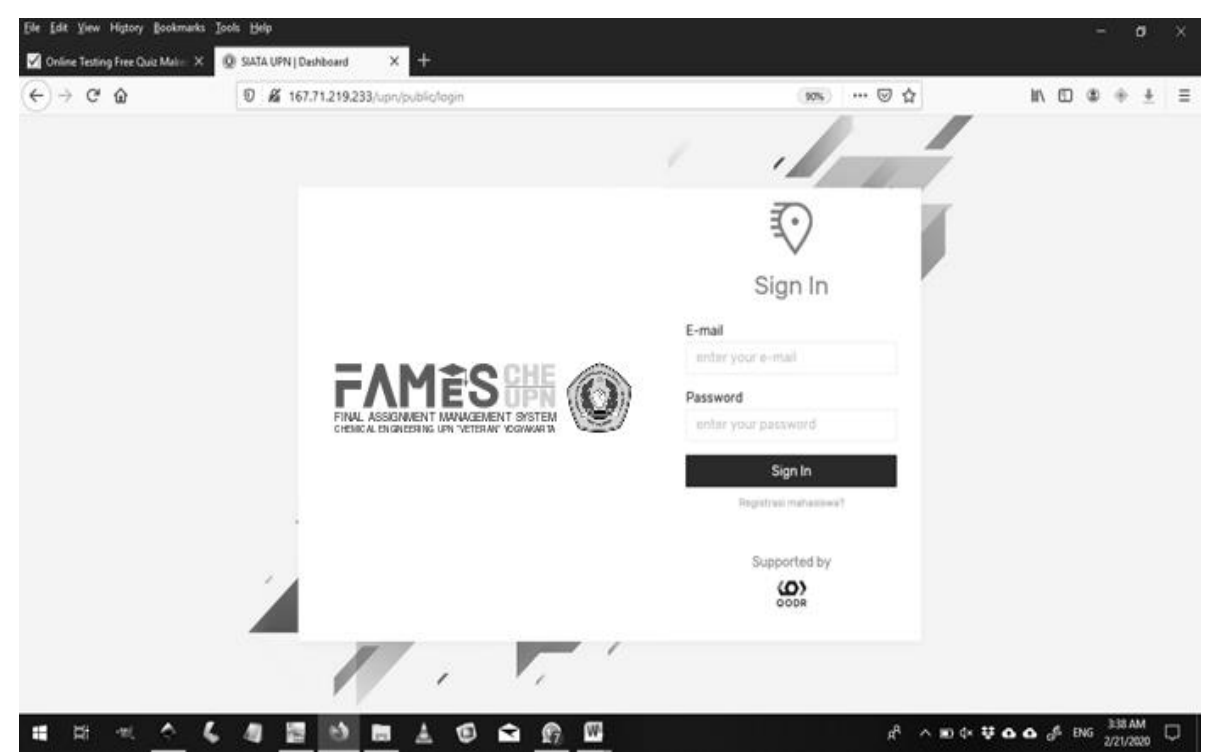

\section{Gambar 4 Halaman Login untuk Memasukkan Username dan Password dan Mengakses Aplikasi}

Pada Gambar 5 ditampilkan dashboard admin sistem. Fungsi admin adalah untuk memelihara database yang berhubungan dengan sistem administrasi, baik terkait dengan dosen, mahasiswa, maupun admin TU. Database ini meliputi daftar pengguna serta data-data yang terkait, seperti username dan password.

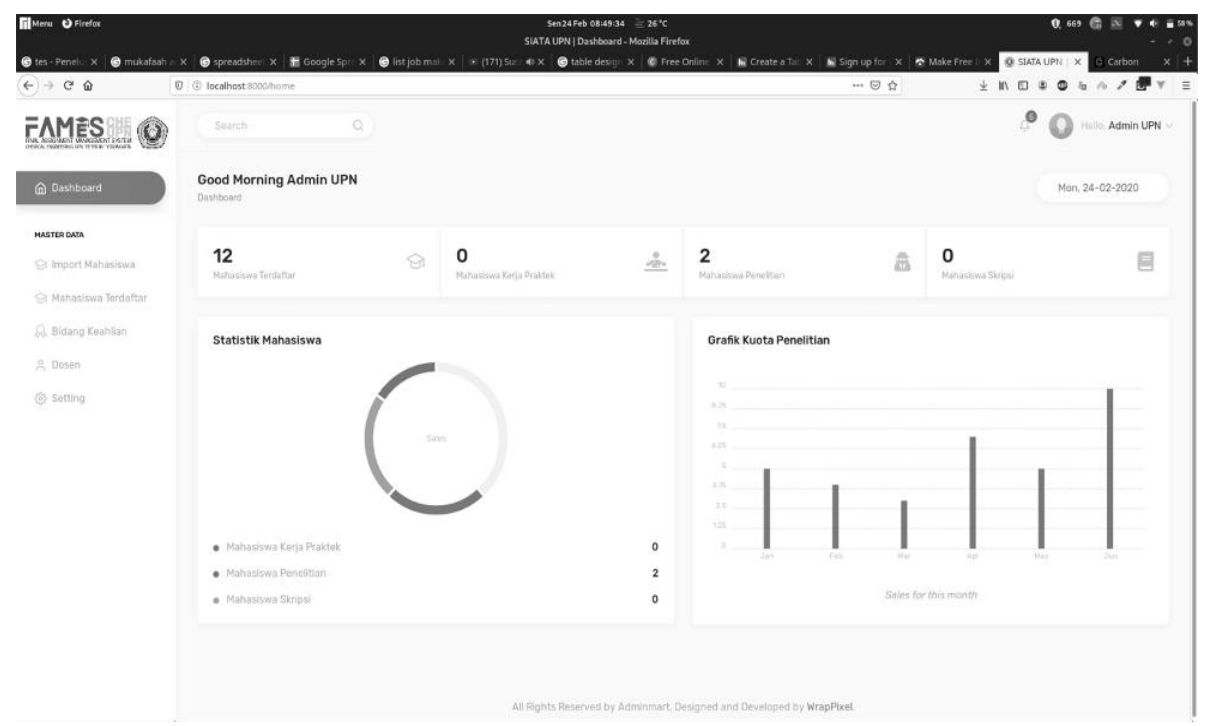

Gambar 5 Dashboard Admin Sistem untuk Pengelolaan Database Pengguna Aplikasi

Berdasarkan pembagian peran seperti dijelaskan pada use case diagram, maka untuk masing masing peran dibuatkan halaman dashboard tersendiri, sesuai dengan fungsi masing - masing. Salah satu tampilan menu untuk mahasiswa ditampilkan pada Gambar 6, yaitu untuk keperluan daftar mata kuliah, sebagai syarat agar mahasiswa bisa melanjutkan ke proses selanjutnya. 


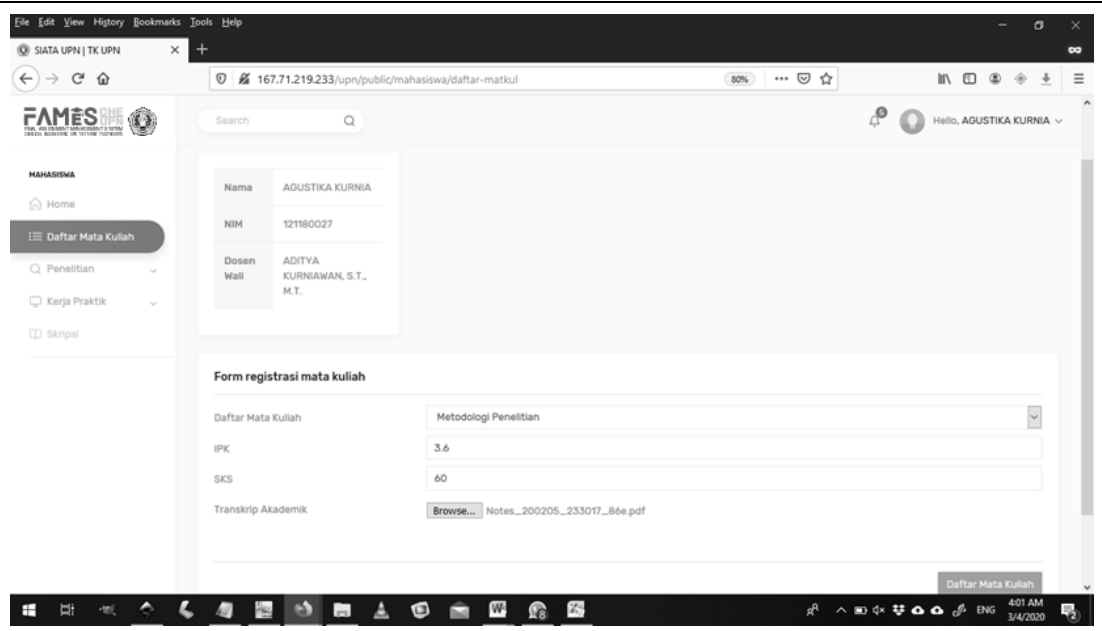

\section{Gambar 6 Tampilan Menu Daftar Mata Kuliah untuk Registrasi Mata Kuliah Tugas Akhir}

Pada Gambar 7 ditampilkan menu administrasi penelitian mahasiswa. Menu ini berfungsi untuk melayani proses administrasi tugas akhir mahasiswa, mulai dari pendaftaran kelompok penelitian, pengumpulan proposal, pendaftaran seminar penelitian, hingga pengumpulan laporan akhir. Menu ditampilkan dalam format step-by-step, sehingga mahasiswa dapat mengikuti langkah-langkah yang harus ditempuh dalam pelaksanaan tugas akhir. Selain itu, disediakan pula fasilitas untuk melaksanakan bimbingan secara online melalui sistem administrasi ini, sehingga data bimbingan dapat tercatat dengan baik. Menu yang serupa disediakan untuk kerja praktik industri dan skripsi.

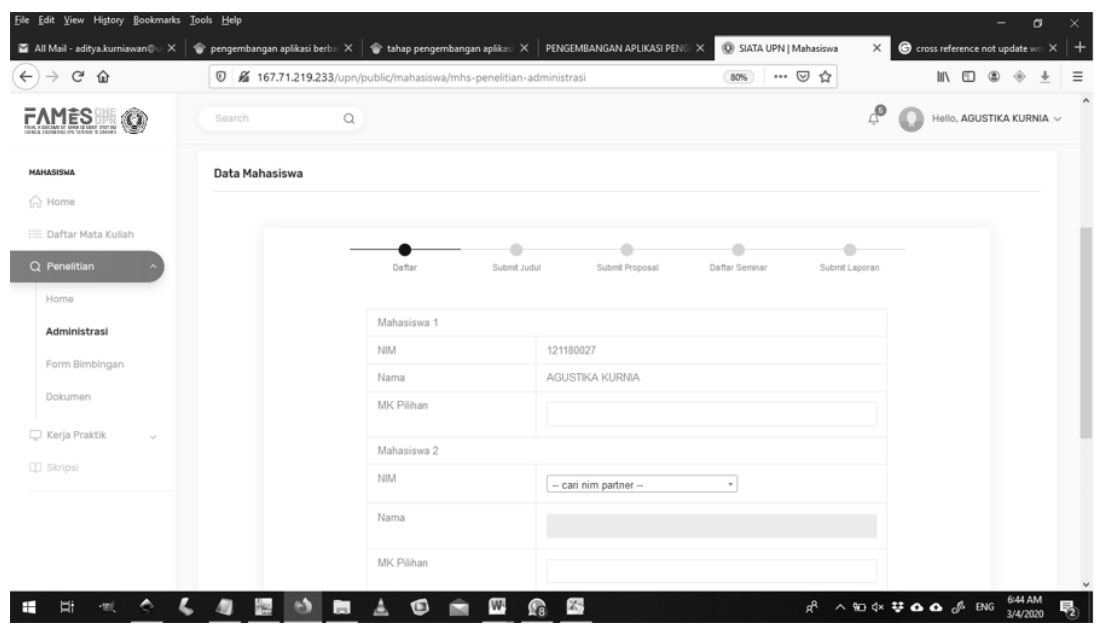

\section{Gambar 7 Menu Administrasi Penelitian Mahasiswa Sesuai dengan SOP Administrasi Tugas Akhir di Jurusan Teknik Kimia}

Adapun menu yang ditampilkan pada dosen dibagi ke dalam menu dasar, untuk memfasilitasi dosen sebagai wali dan pembimbing tugas akhir, serta menu untuk dosen koordinator tugas akhir, dosen mata kuliah tugas akhir, dan pengurus jurusan (ketua jurusan dan koordinator prodi). Menu untuk masing-masing aktor tersebut ditunjukkan pada Gambar 8. Untuk menunjang fungsi dosen pembimbing/wali, maka disediakan fasilitas untuk bimbingan secara online serta fasilitas pesan untuk memberikan persetujuan, seperti persetujuan judul, proposal serta laporan akhir. Dosen pembimbing hanya dapat mengakses data tugas akhir mahasiswa yang merupakan bimbingannya. Adapun dalam menunjang tugas koordinator tugas akhir, disediakan menu untuk mendisitribusikan pembimbing, menyetujui judul, serta fungsi-fungsi lainnya. Dosen koordinator dapat mengakses data tugas akhir mahasiswa yang ada di bawah koordinasinya. Adapun untuk pengurus jurusan, diberikan hak untuk mengakses data seluruh mahasiswa dan dosen, tetapi tidak bisa melakukan persetujuan/pengubahan data tugas akhir. 


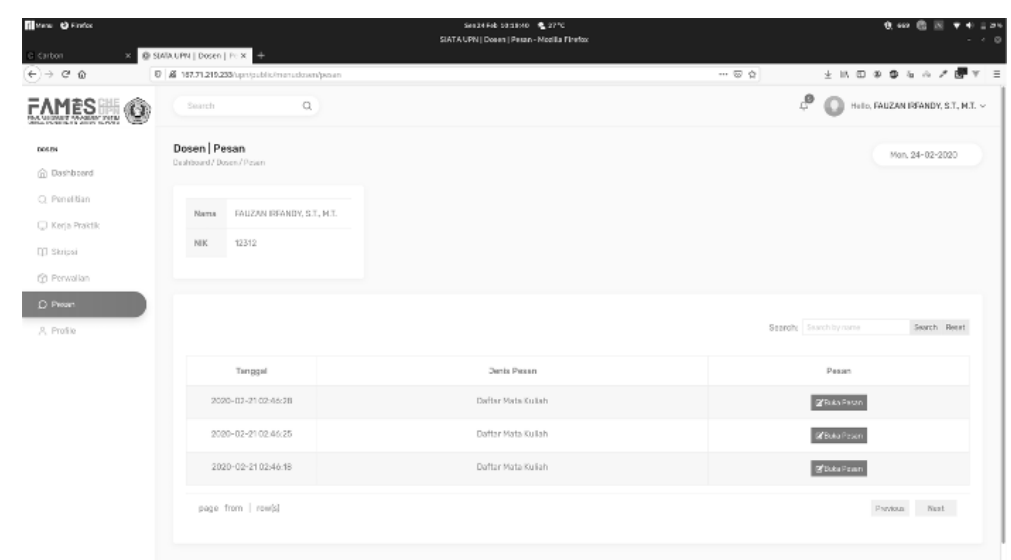

(a)

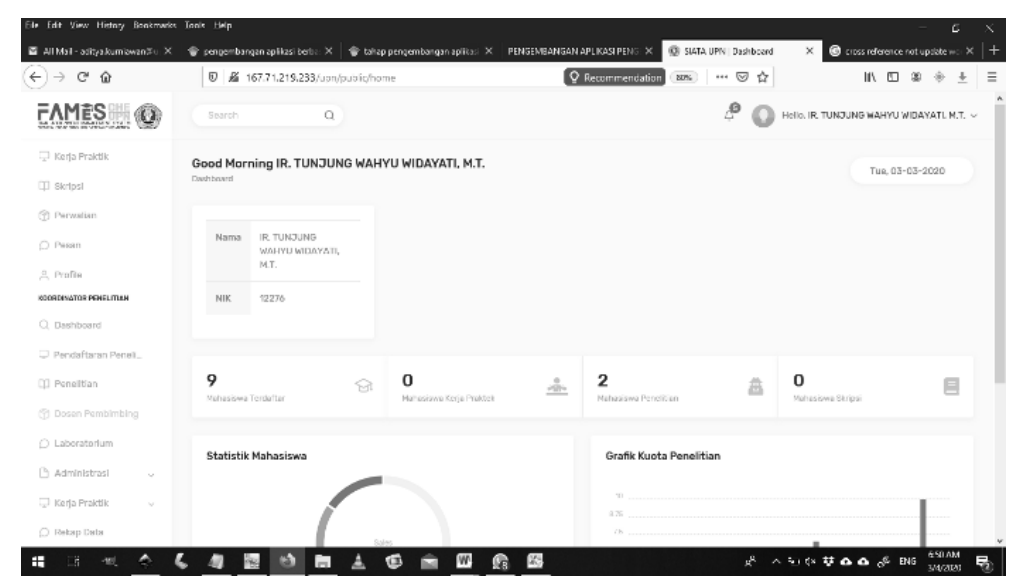

(b)

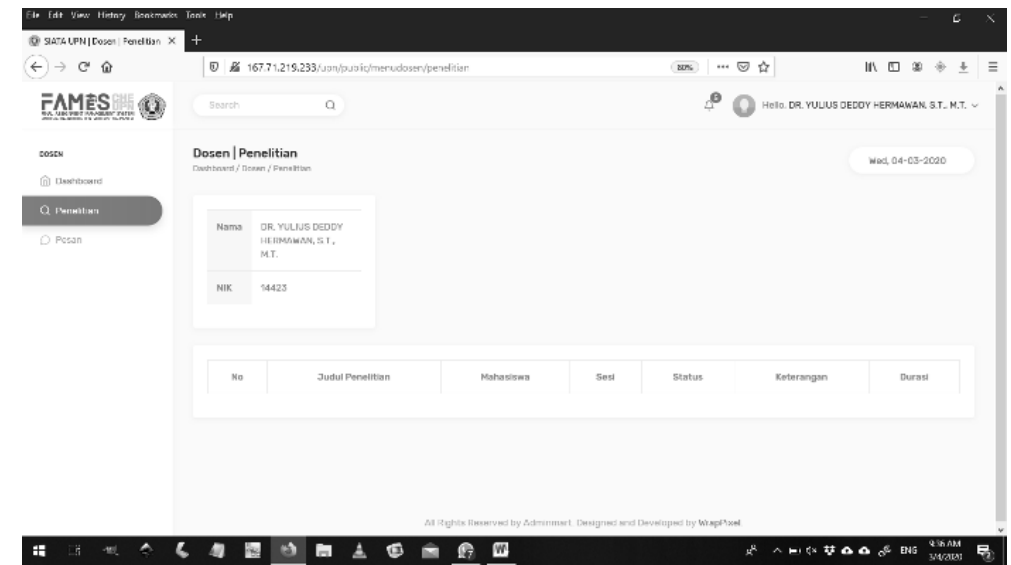

(c)

Gambar 8 Menu Dosen untuk Berbagai Jabatan/Tugas Dosen (A) Dosen Biasa (B) Dosen Koordinator Tugas Akhir (C) Pengurus Jurusan 


\section{KESIMPULAN}

Dari hasil penelitian ini, telah berhasil disusun suatu rancangan aplikasi sistem administrasi tugas akhir program studi S1 Teknik Kimia UPN "Veteran" Yogyakarta. Selanjutnya, rancangan dari sistem administrasi Implementasi dari rancangan aplikasi ini telah dilakukan dengan menggunakan kerangka kerja Laravel, dengan bahasa pemrograman PHP dan database MySQL. Sistem administrasi yang dapat memudahkan mahasiswa dalam melakukan pengurusan administrasi tugas akhir, serta mempermudah bagi pihak jurusan, meliputi dosen wali/pembimbing, koordinator tugas akhir, dan pengurus jurusan dalam melakukan pemantauan dan pengendalian pelaksanaan tugas akhir, sehingga diharapkan pelaksanaan tugas akhir mahasiswa akan lebih baik dan lebih cepat. Selain itu, dengan pengelolaan data tugas akhir yang lebih rapi, penyiapan data untuk keperluan akreditasi dan pengambilan keputusan oleh pengurus jurusan akan lebih praktis.

\section{DAFTAR PUSTAKA}

Al-Fedaghi, S. (2011). Developing Web Applications. International Journal of Software Engineering and Its Applications.

Hidayati, N., \& Hadi, S. (2017). ANALISA DAN PERANCANGAN SISTEM INFORMASI AKADEMIK DAN KEUANGAN ONLINE PADA PERGURUAN TINGGI. SINTAK.

Jannah, E. N., Bayturrohman, D. K., \& Kurniawan, E. (2017). Pengembangan Aplikasi Penerimaan Mahasiswa Baru Berbasis Android Dilengkapi dengan Fitur Push Notification. Jurnal Nasional Teknik Elektro dan Teknologi Informasi (JNTETI).

Kadir, A., \& Triwahyuni, T. C. (2013). Pengantar Teknologi Informasi. Yogyakarta: Penerbit Andi.

Musmini, L. S., \& Kertiasih, N. K. (2016). Sistem Administrasi Akademik Jurusan D3 Akuntansi Berbasis Teknologi Informasi. Jurnal Pendidikan Teknologi dan Kejuruan (JPTK).

Nugroho, B., \& Putra, A. B. (2016). SISTEM INFORMASI PENGELOLAAN ADMINISTRASI TUGAS AKHIR DI JURUSAN TEKNIK INFORMATIKA UPN "VETERAN" JAWA TIMUR. Jurnal Sistem Informasi Dan Bisnis Cerdas (SIBC), 9(1), 25-34.

Raafi'Udin, R. D. (2017). Perancangan Sistem Informasi Tracerstudy Menggunakan Aplikasi Open Source Di Universitas. Jurnal Sisfokom (Sistem Informasi dan Komputer).

Rendro Prasetyo, I. I. (2010). Perancangan Sistem Informasi Tugas Akhir dan Kerja Praktek di Jurusan Teknik Industri UNS. Performa, 9(1), 55-63.

Setiawan, R., \& Nurfadilah, Y. (2016). Pengembangan Aplikasi Pengendalian Tugas Akhir Berbasis Web Sisi Mahasiswa, Dosen, dan Staff USI. Algoritma, 34-40.

Solichin, A. (2016). Pemrograman Web dengan PHP dan MySQL. Jakarta: Penerbit Budi Luhur.

Sukamto, T. S., Nugroho, L. E., \& Winarno, W. W. (2016). Desain Sistem Informasi Akreditasi Program Studi Berbasis Website di Indonesia. Seminar Nasional Aplikasi Teknologi Informasi (SNATI).

Susilo, P., \& Rohman, M. (2019). ). Efektivitas Sistem Pembelajaran Online sebagai Media Pembelajaran Berbasis Aplikasi Web di Era Milenial. Seminar Nasional Sistem Informasi (SENASIF).

Taftayani, M. B., Gumilang, S. F., \& Lubis, M. (2019). Perancangan Aplikasi Pendidikan Berbasis Website Menggunakan Framework Laravel Dan Framework Css Materialize Pada Startup Sinau Yo. eProceedings of Engineering.

\section{UCAPAN TERIMAKASIH}

Penulis mengucapkan terimakasih sebesar-besarnya kepada LPPM-UPN "Veteran" Yogyakarta atas dukungan finansial melalui skema hibah kelembagaan dengan Nomor kontrak: B/286/UN.62/PT/X/2019. 